\title{
Design, Development \& Evaluation of a Poly herbal Syrup from some herbs used as Energy booster.
}

\section{Research article}

\author{
Swain Pramod Kumar ${ }^{*}$, Nayak Durga Prasan ${ }^{2}$ \\ 1. Scientific Officer (Chemistry), State Drug Testing \& Research Laboratory (ISM), \\ Govt. of Odisha, Govt. Ayurvedic Hospital Campus, BJB-Nagar, Bhubaneswar-751014, \\ Odisha \\ 2. Indira Gandhi Institute of Pharmaceutical Sciences, N4/ 208, IRC Village, Nayapalli, \\ Bhubaneswar, Odisha
}

\begin{abstract}
Ayurvedic formulations are preferentially administered by oral route, and most of the orally administered Ayurvedic formulations belong to liquid form of drug or drug combination. However herbal medicinal products have to fulfill the legal requirements with regard to quality including stability testing. Designing as well as shelf-life determination of oral herbal formulations is till date a challenge in modern pharmaceutics. A locally used polyherbal formulation from Withania somnifera Dunal, Asparagus racemosos Wild, Bombax malabaricum, Glycyrrhiza glabra Linn. Elettaria cardamomum Maton Var., Cinnamomum zelylanicum Nees, is used as energy booster. In present study the formulation was selected for designing developing and evaluation of a polyherbal syrup from it. The prepared poly herbal syrup was evaluated immediately after preparation and all the tested parameter along with turbidity/homogeneity were compared with the changes in accelerated stability testing. The final syrup was found to have $\mathrm{pH} 4.25$ and specific gravity $1.2054 \mathrm{~g} / \mathrm{ml}$. The results of stability study of the final syrup reveal that no changes were noticed in all the tested physicochemical parameter as well as turbidity/homogeneity during $24 \mathrm{hr}, 48 \mathrm{hr}$ and 72 hr.
\end{abstract}

Key Words: - Poly herbal formulation, Liquid dosage form, Syrup, Physicochemical parameter, Accelerated stability Studies.

\section{Introduction}

A successful formulation of liquids, as well as other dosage forms, requires a blend of scientific acuity and pharmaceutical "art" (1). Oral liquid medicines are being superseded gradually by tablets and capsules because of

*Corresponding Author:

\section{Pramod Kumar Swain}

Scientific Officer (Chemistry),

State Drug Testing \& Research Laboratory(ISM), Govt. of Odisha,

Govt. Ayurvedic Hospital Campus, BJB

Nagar, Bhubaneswar-751014

Email: tstm_22@yahoo.co.in deleterious changes take place more readily in solution (2). Nevertheless there are still a large number of liquid oral preparations are available in the official books. The fact is that the absorption of medicaments in solution form from the GI tract into the systemic circulation may be expected to occur more rapidly than other oral dosage forms of the same medicinal agent (3). Ayurvedic formulations are preferentially administered by oral route (4), and most of the orally administered Ayurvedic formulations belong to liquid form of drug or drug combination. However herbal medicinal products have to fulfill the legal requirements with regard 
to quality including stability testing, but have certain particularities such as a complex nature, an often low concentration of constituents and a natural variability of their raw materials $(5,6)$. Designing as well as shelf-life determination of oral herbal formulations is till date a challenge in modern pharmaceutics. There are number of medicinal herbs are described in Ayurveda which are time tested, and useful for the number of aliment.

A locally used polyherbal formulation from Aswagandha(Withania somnifera Dunal, F- Solanaceae) (7), Satamuli(Asparagus racemosos Wild, FLiliaceae) (8), Moca(Bombax malabaricum, F-Malvaceae) (9), Yastika(Glycyrrhiza glabra Linn., FLeguminosae) (10), Ela(Elettaria cardamomum Maton Var., FZingiberaceae) (11) and Darusita(Cinnamomum zelylanicum Nees, F-Lauraceae) (12) is used as energy booster, in loss of strength, vigor, vitality and ill health, Heamatinic and stress. In present study the locally used poly herbal formulation was selected for designing, developing and evaluation of a polyherbal syrup from it.

\section{Materials \& Methods \\ Plant material:}

The crude drugs, dried roots of Withania somnifera Dunal, dried roots of Asparagus racemosos Wild, exudates from the stem bark of Bombax malabaricum, dried roots of Glycyrrhiza glabra Linn., dried fruits of Elettaria cardamomum Maton Var., and dried stem bark of Cinnamomum zelylanicum Nees. were procured from the local crude drug shop, Vaidya store and their identity was confirmed by correlating their morphological and microscopical characters with those given in literature.

Development of herbal syrup:

a) Local formulation:- ( Each $500 \mathrm{~g}$ of powder contains)

Aswagandha $-139 \mathrm{~g}$
Asparagus $\quad-139 \mathrm{~g}$
Bombax $\quad-139 \mathrm{~g}$
Yastika $\quad-069 \mathrm{~g}$
Ela $\quad-007 \mathrm{~g}$
Darusita $\quad-007 \mathrm{~g}$

b) Method of preparation of decoction $(13,14):-500 \mathrm{~g}$ of the prepared formulation was taken and mixed with $4000 \mathrm{ml}$ of water. The mixture was boiled until total volume become one fourth of the initial volume. Then the decoction was cooled and filtered. Filtrate was taken to prepare final herbal syrup.

c) Method of preparation of simple syrup (USP):- $666.7 \mathrm{~g}$ of Sucrose was weighed and added to purified water and heated until it dissolved with occasional stirring. Sufficient boiling water was added to produce $1000 \mathrm{ml}$.

d) Method of preparation of final herbal syrup: - one part of decoction was mixed with five parts of simple syrup (1:5). Required quantity of Sodium benzoate $(0.2 \%)$ was added as preservative to the above mixture. Solubility was checked by observing the clarity of solution visually. The final herbal syrup was then subjected for evaluation.

\section{Evaluation of herbal syrup:}

Physicochemical parameters $(15,16,17$, 18):- the herbal syrup was evaluated for various physicochemical parameters such as physical appearance (colour, odour, taste), $\mathrm{pH}, \mathrm{Wt} / \mathrm{ml}$ and Specific Gravity. 
a) Color examination: - Five ml final syrup was taken into watch glasses and placed against white back ground in white tube light. It was observed for its color by naked eye.

b) Odor examination: - Two $\mathrm{ml}$ of final syrup was smelled individually. The time interval among two smelling was kept 2 minutes to nullify the effect of previous smelling.

c) Taste examination: - A pinch of final syrup was taken and examined for its taste on taste buds of the tongue.

d) Determination of pH: - Placed an accurately measured amount $10 \mathrm{ml}$ of the final syrup in a $100 \mathrm{ml}$ volumetric flask and made up the volume up to $100 \mathrm{ml}$ with distilled water. The solution was sonicated for about 10 minutes. $\mathrm{pH}$ was measured with the help of digital $\mathrm{pH}$ meter.

e) Specific gravity at $25^{0} \mathrm{C}$ :- A thoroughly clean and dry Pycnometer was selected and calibrated by filling it with recently boiled and cooled water at $25^{\circ} \mathrm{C}$ and weighing the contents. Assuming that the weight of $1 \mathrm{ml}$ of water at $25^{\circ} \mathrm{C}$ when weighed in air of density $0.0012 \mathrm{~g} / \mathrm{ml}$ was $0.99602 \mathrm{~g}$. The capacity of the Pycnometer was calculated. Adjusting the temperature of the final syrup to about $20^{\circ} \mathrm{C}$ and the Pycnometer was filled with it. Then the temperature of the filled Pycnometer was adjusted to $25^{\circ} \mathrm{C}$, any excess syrup was removed and weight was taken. The tare weight of the Pycnometer was subtracted from the filled weight. The weight per milliliter was determined by dividing the weight in air, expressed in $\mathrm{g}$, of the quantity of syrup which fills the Pycnometer at the specified temperature, by the capacity expressed in $\mathrm{ml}$, of the Pycnometer at the same temperature. Specific gravity of the final syrup was obtained by dividing the weight of the syrup contained in the Pycnometer by the weight of water contained, both determined at $25^{\circ} \mathrm{C}$.

\section{Stability testing:}

Stability testing of the prepared poly herbal syrup was performed on keeping the samples at accelerated temperature conditions. Nine portions of the final syrup $(1 \mathrm{~A}, 1 \mathrm{~B}, 1 \mathrm{C}, 2 \mathrm{~A}, 2 \mathrm{~B}, 2 \mathrm{C}$, $3 \mathrm{~A}, 3 \mathrm{~B}$ and $3 \mathrm{C}$ ), were taken in amber colored glass bottles and were kept at accelerated temperature at $4^{0} \mathrm{C}$, Room temperature and $47^{\circ} \mathrm{C}$ respectively. The samples were tested for all the physicochemical parameters, turbidity and homogeneity at the interval of $24 \mathrm{hr}, 48 \mathrm{hr}$ and $72 \mathrm{hr}$ to observe any change.

Table:-1 Result of Physicochemical parameters of developed poly herbal syrup.

\begin{tabular}{|c|c|c|}
\hline $\begin{array}{c}\text { Sl. } \\
\text { No. }\end{array}$ & Physicochemical parameters & Observed Values \\
\hline 1 & Color & Reddish \\
\hline 2 & Odor & Pleasant odor \\
\hline 3 & Taste & Sweet \\
\hline 4 & $\mathrm{pH}$ & 4.25 \\
\hline 5 & $\mathrm{Wt} / \mathrm{ml}$ at $25^{\circ} \mathrm{C}$ & $1.18995 \mathrm{~g}$ \\
\hline 6 & Specific gravity & $1.2054 \mathrm{~g} / \mathrm{ml}$ \\
\hline
\end{tabular}


Table:-2 Stability studies through Physicochemical parameters of developed poly herbal Syrup.

\begin{tabular}{|c|c|c|c|c|c|c|c|c|c|}
\hline \multirow{2}{*}{$\begin{array}{l}\text { Sampl } \\
\text { e Code }\end{array}$} & \multirow{2}{*}{$\begin{array}{c}\text { Time } \\
\text { Duratio } \\
\text { n (in } \\
\text { hour) }\end{array}$} & \multirow{2}{*}{$\begin{array}{l}\text { Temperatur } \\
\text { e }\left({ }^{0} \mathbf{C}\right)\end{array}$} & \multicolumn{7}{|c|}{ Physicochemical parameters } \\
\hline & & & $\begin{array}{c}\text { Colo } \\
\mathbf{r}\end{array}$ & $\begin{array}{c}\text { Odo } \\
\mathbf{r}\end{array}$ & $\begin{array}{c}\text { Tast } \\
\text { e }\end{array}$ & pH & $\begin{array}{c}\mathrm{Wt} / \mathrm{ml} \\
\text { at } \\
25^{0} \mathrm{C}\end{array}$ & $\begin{array}{c}\text { Specifi } \\
\text { c } \\
\text { gravity }\end{array}$ & $\begin{array}{c}\text { Turbidity/ } \\
\text { Homogeneity }\end{array}$ \\
\hline $1 \mathrm{~A}$ & $24 \mathrm{hr}$ & $4^{0} \mathrm{C}$ & $\mathrm{NC}$ & $\mathrm{NC}$ & $\mathrm{NC}$ & $\begin{array}{c}4.2 \\
5\end{array}$ & $\begin{array}{l}1.1899 \\
5 \mathrm{~g}\end{array}$ & $\begin{array}{l}1.2054 \\
\mathrm{~g} / \mathrm{ml}\end{array}$ & $\begin{array}{c}\text { No } \\
\text { Turbidity }\end{array}$ \\
\hline $1 \mathrm{~B}$ & & Room temp & $\mathrm{NC}$ & $\mathrm{NC}$ & $\mathrm{NC}$ & $\begin{array}{c}4.2 \\
5\end{array}$ & $\begin{array}{l}1.1899 \\
5 \mathrm{~g}\end{array}$ & $\begin{array}{l}1.2054 \\
\mathrm{~g} / \mathrm{ml}\end{array}$ & $\mathrm{X}$ \\
\hline $1 \mathrm{C}$ & & $47^{0} \mathrm{C}$ & $\mathrm{NC}$ & $\mathrm{NC}$ & $\mathrm{NC}$ & $\begin{array}{c}4.2 \\
5\end{array}$ & $\begin{array}{l}1.1899 \\
5 \mathrm{~g}\end{array}$ & $\begin{array}{l}1.2054 \\
\mathrm{~g} / \mathrm{ml}\end{array}$ & $\begin{array}{c}\text { Homogeneit } \\
\mathrm{y}\end{array}$ \\
\hline $2 \mathrm{~A}$ & $48 \mathrm{hr}$ & $4^{0} \mathrm{C}$ & $\mathrm{NC}$ & $\mathrm{NC}$ & $\mathrm{NC}$ & $\begin{array}{c}4.2 \\
5\end{array}$ & $\begin{array}{l}1.1899 \\
5 \mathrm{~g}\end{array}$ & $\begin{array}{l}1.2054 \\
\mathrm{~g} / \mathrm{ml}\end{array}$ & $\begin{array}{c}\text { No } \\
\text { Turbidity }\end{array}$ \\
\hline $2 B$ & & Room temp & $\mathrm{NC}$ & $\mathrm{NC}$ & $\mathrm{NC}$ & $\begin{array}{c}4.2 \\
5\end{array}$ & $\begin{array}{l}1.1899 \\
5 \mathrm{~g}\end{array}$ & $\begin{array}{l}1.2054 \\
\mathrm{~g} / \mathrm{ml}\end{array}$ & $X$ \\
\hline $2 \mathrm{C}$ & & $47^{0} \mathrm{C}$ & $\mathrm{NC}$ & $\mathrm{NC}$ & $\mathrm{NC}$ & $\begin{array}{c}4.2 \\
5\end{array}$ & $\begin{array}{l}1.1899 \\
9 \mathrm{~g}\end{array}$ & $\begin{array}{l}1.2055 \\
\mathrm{~g} / \mathrm{ml}\end{array}$ & $\begin{array}{c}\text { Homogeneit } \\
\mathrm{y}\end{array}$ \\
\hline $3 \mathrm{~A}$ & $72 \mathrm{hr}$ & $4^{0} \mathrm{C}$ & $\mathrm{NC}$ & $\mathrm{NC}$ & $\mathrm{NC}$ & $\begin{array}{c}4.2 \\
5\end{array}$ & $\begin{array}{l}1.1899 \\
5 \mathrm{~g}\end{array}$ & $\begin{array}{l}1.2054 \\
\mathrm{~g} / \mathrm{ml}\end{array}$ & $\begin{array}{c}\text { No } \\
\text { Turbidity }\end{array}$ \\
\hline $3 \mathrm{~B}$ & & Room temp & $\mathrm{NC}$ & $\mathrm{NC}$ & $\mathrm{NC}$ & $\begin{array}{c}4.2 \\
5\end{array}$ & $\begin{array}{l}1.1899 \\
5 \mathrm{~g}\end{array}$ & $\begin{array}{l}1.2054 \\
\mathrm{~g} / \mathrm{ml}\end{array}$ & $X$ \\
\hline $3 \mathrm{C}$ & & $47^{0} \mathrm{C}$ & $\mathrm{NC}$ & $\mathrm{NC}$ & $\mathrm{NC}$ & $\begin{array}{c}4.2 \\
5\end{array}$ & $\begin{array}{l}1.1902 \\
9 \mathrm{~g}\end{array}$ & $\begin{array}{l}1.2058 \\
\mathrm{~g} / \mathrm{ml}\end{array}$ & $\begin{array}{c}\text { Homogeneit } \\
\mathrm{y}\end{array}$ \\
\hline
\end{tabular}

$\mathrm{NC}=$ No Change, $\mathrm{X}=$ Original condition

\section{Results and Discussion:}

The stability evaluation of pharmaceutical preparations by observing them for a year or more, corresponding to the normal time that they would remain in stock and in use was time consuming. In order to avoid this problem accelerated stability study is used by most of the pharmaceuticals for stability evaluation of all types of formulations (19). Though the primary aim of this work was to develop poly herbal syrup but the stability study will mark an important advancement in the area of phytopharmaceuticals.

The prepared syrup was evaluated immediately after preparation and all the tested parameter along with turbidity/homogeneity were compared with the changes in accelerated stability testing. The final syrup found to have $\mathrm{pH}$ 4.25 and specific gravity $1.2054 \mathrm{~g} / \mathrm{ml}$ (Table 1). The results of stability study of the final syrup (Table-2) reveal that no changes were noticed in all the tested physicochemical parameter as well as turbidity/homogeneity during $24 \mathrm{hr}, 48 \mathrm{hr}$ and $72 \mathrm{hr}$. Thus it can be concluded that the prepared poly herbal syrup may be used as a stable liquid dosage form and the results of the accelerated stability study may help for further studies of shelf-life of poly herbal syrup in near future.

\section{References:}

1. Lachman L., Lieberman HA, Kanig JL. The Theory and Practice of Industrial Pharmacy. $3^{\text {rd }}$ ed. Bombay; Varghese Publishing House; 1987. 457p.

2. Carter SJ. Dispensing for Pharmaceutical Students. $12^{\text {th }}$ ed. New Delhi; CBS Publishers \& Distributors; 2000. 67p.

3. Ghiware N.B, Gattani S.G, Chalikwar S.S. Design, Development and Evaluation of Oral Herbal Formulation of Piper nigrum and Nyctanthes arbortristis. International Journal of Pharm Tech Research. 2010; 2(1) ; 171-176. 
4. Ansel HC, Allen LV. Pharmaceutical dosage form and drug delivery systems. $7^{\text {th }}$ ed. Lippincott; 2000. 347$356 \mathrm{p}$.

5. Stability testing for new dosage forms. QIC. (ICH), International Conference on Harmonization. 1996.

6. Deepa P, Kannappan N. Comparative Stability study of formulated Ayurvedic health supplement and marketed product. Der' Pharma Chemica. 2012; 4(5); 2068-2072.

7. The Ayurvedic Pharmacopoeia of India. Govt. of India; Ministry of Health \& Family Welfare Dept. of ISM\&H; Part-I, Vol-I. New Delhi; Controller of Publications; 2008. 15$16 \mathrm{p}$.

8. Kokate C.K, Purohit A.P, Gokhale S.B. Pharmacognosy. $16^{\text {th }}$ ed. Pune; Nirali Prakashan; 2001. 213-214p.

9. The Review of Applied Entomology. Agricultural. Volume 61.

10. The Ayurvedic Pharmacopoeia of India. Govt. of India; Ministry of Health \& Family Welfare Dept. of ISM\&H; Part-I, Vol-I. New Delhi; Controller of Publications; 2008. 127$128 \mathrm{p}$.
11. Kokate C.K, Purohit A.P, Gokhale S.B. Pharmacognosy. $16^{\text {th }}$ ed. Pune; Nirali Prakashan; 2001. 319-322p.

12. Kokate C.K, Purohit A.P, Gokhale S.B. Pharmacognosy. $16^{\text {th }}$ ed. Pune; Nirali Prakashan; 2001. 334-336p.

13. Khory R.N. Principles and Practice of Ayurvedic Medicines. Volume-I. New Delhi; Biotech Books; 2004. 211-219p.

14. Patel D.A, Patel Y.K, Shah P.B. Development and Evaluation of herbal syrup from Neolamarckla cadamba Roxb. Bosser leaves. International Research Journal of Pharmacy. 2012; 3(9); 201-202.

15. Public Draft. WHO Guidelines for Herbal Drug Standardization. 2004.

16. Shailesh N. Suvarna Bhasma. Pharma Time. 2005; 37(6); 23.

17. Indian Pharmacopoeia. Govt. of India; Ministry of Health \& Family Welfare; Vol-II. Delhi; Controller of Publications; 1986. A-99.

18. Narayana D.B.A. Stability Studies of Ayurvedic Formulations. Pharma Times. 2005; 37(6); 45-50.

19. Chauhan S.K, Agarwal S. Stability studies of herbal drugs. The Eastern Pharmacist. 1999; 35-36. 